TESTIMONIOS DE AFECTO Y AMISTAD

Revista Atlántica-Mediterránea 22, pp. 11-41

BIBLID [2445-3072 (2020) 22, 1-443]

https://doi.org/10.25267/rev_atl-mediterr_prehist_arqueol_soc.2020.v22.05

\title{
HOMENAJE A ANTONIO SÁEZ ESPLIGARES
}

\section{María del Carmen ORCERO}

\section{Historiadora. Universidad de Cádiz}

Conocí personalmente a Antonio Sáez a finales de 1989. Puntualizo la palabra personalmente, porque durante el tiempo en que estudié Historia en la Facultad, su nombre era ya conocido entre los estudiantes, mucho más en mi caso, al darse la circunstancia de ser paisanos. En esa época, él ya llevaba unos años dedicado a la arqueología en estrecha vinculación con el Museo de Cádiz. Antonio fue para mí, durante mi etapa universitaria, el profesional que representaba el trabajo arqueológico que se llevaba a cabo en la ciudad de ambos: San Fernando.

Durante el año 90, trabajé en la Biblioteca Lobo de San Fernando gracias a un programa de empleo denominado Andalucía Joven. Esta iniciativa reunió, en distintas dependencias del Ayuntamiento, a jóvenes profesionales de diferentes ámbitos, entre ellos un grupo de recién licenciados en Historia. La Biblioteca Lobo estaba situada dentro del edificio consistorial, a muy pocos metros de aquella entreplanta donde se empezaba a conformar la colección que con los años se ha convertido en el actual Museo Municipal. Recuerdo de forma nítida todas y cada una de las visitas que hice a ese germen de museo al que Antonio Sáez iba dando vida. Eran visitas que disfruté porque él, con la amabilidad y, sobre todo, con la pasión que siempre ha tenido por la arqueología, las convertía en verdaderas clases magistrales. Nos iba explicando la importancia y las características de cada una de las piezas de las que constaba entonces la colección.

A partir de ahí, no me fue difícil seguir de cerca su carrera profesional, ya que eran continuas las noticias que me llegaban de sus investigaciones, su implicación en proyectos culturales, así como de una lucha continua, a lo largo de los años, para dotar a San Fernando de un museo digno de la Historia que él sabe que esta ciudad puede contar.

Curiosamente, por cuestiones del azar, volví a encontrarme con él, en un entorno profesional, muchos años después. Tuve la suerte de trabajar a sus órdenes en la hemeroteca municipal a lo largo del último año en que el museo estuvo situado en la Calle Real. En esa ocasión, el grupo de trabajo al que yo pertenecía visitamos con él el Castillo de San Romualdo, sede actual del museo. Tengo que decir que a pesar de los años que habían pasado, me llevé una grata sorpresa, me encontré con el mismo profesional con el que tuve la suerte de compartir aquel año 90, bajo las bóvedas del museo que nacía en el Ayuntamiento. Tuvo la amabilidad de guiarnos por el castillo como solo puede hacerlo alguien que vivió de cerca las excavaciones, los hallazgos y el trabajo de investigación con el que se sentaron las bases de la evolución histórica del edificio. A título personal, tengo que decir que aquel día tuve la sensación de que en el corto camino que recorrimos de su despacho al castillo, Antonio volvía a retomar los útiles y las herramientas de excavación para describir el trabajo de campo. Escuchando sus explicaciones didácticas, volví a reafirmarme en la idea de que, a pesar de los inconvenientes del camino, no hay nada más edificante que dedicar la vida profesional a lo que realmente apasiona.

Desde aquí, solo puedo expresar mi más profundo agradecimiento a Antonio Sáez. Creo que nuestra ciudad le debe mucho. Sin su labor, San Fernando no sería culturalmente la misma. Aprovecho para agradecerle, además, ese entusiasmo tan suyo del que antes escribía. Sé que fue capaz de transmitirlo a un grupo de jóvenes que ahora se han convertido en magníficos profesionales de la Arqueología, entre ellos su hijo.

Gracias, Antonio, por toda una vida dedicada a la Cultura. 